\title{
The Renewal of Arts, Lives, and a Community through Social Enterprise: The Case of Oficina de Agosto
}

\author{
Luciana Walther $1, *(\mathbb{D})$ and Carlos Eduardo Félix da Costa ${ }^{2}$ \\ 1 Department of Business and Accounting Sciences, Federal University of São João del-Rei, \\ Sao Joao Del Rei 36325-000, Brazil \\ 2 Department of Arts and Design, Pontifical Catholic University of Rio de Janeiro, \\ Rio de Janeiro 22541-041, Brazil; eduardo.felix.costa@gmail.com \\ * Correspondence: lucianawalther@ufsj.edu.br
}

check for updates

Citation: Walther, L.; da Costa, C.E.F. The Renewal of Arts, Lives, and a Community through Social Enterprise: The Case of Oficina de Agosto. Sustainability 2022, 14, 125. https://doi.org/10.3390/su14010125 Academic Editors: John Schouten, Melea Press and Beth DuFault

Received: 4 October 2021

Accepted: 14 December 2021

Published: 23 December 2021

Publisher's Note: MDPI stays neutral with regard to jurisdictional claims in published maps and institutional affiliations.

Copyright: (c) 2021 by the authors Licensee MDPI, Basel, Switzerland. This article is an open access article distributed under the terms and conditions of the Creative Commons Attribution (CC BY) license (https:// creativecommons.org/licenses/by/ $4.0 /)$.

\begin{abstract}
The present work investigates, with a cultural approach, the emergence of an art-based social enterprise and an art-entrepreneurial ecosystem in Southeastern semi-rural Brazil, shedding light on how local private initiatives may build stronger communities and vice-versa, in a mutually transformative relationship. The focus lies on Oficina de Agosto, a folk-art studio, school, and shop. Fieldwork design combined ethnography and art-based research. The thick description of the phenomenon is organized under the acronym P.L.A.C.E., a conceptual framework describing five principles of community development. The contributions of this study are three-fold: (1) it illustrates how social enterprise may work as an alternative market model that could support community building; (2) it raises awareness to the possibility that social enterprises' initial social focus may not be perennial or unshakeable, in an undesirable change that might require a both/and mindset and a patient management of paradoxes; and (3) it offers practical managerial recommendations to the SE under focus, which might be extended to other local businesses, or to SEs in other semi-rural Brazilian towns, or even in international settings that might bear economic and social resemblance to our researched context.
\end{abstract}

Keywords: social enterprise; paradox management; place; rural; community; tourism; arts and crafts; art-based research; ethnography; global South

\section{Introduction}

The present work investigates, with a cultural approach, the emergence of an art-based social enterprise (SE) and an art-entrepreneurial ecosystem in Southeastern semi-rural Brazil, shedding light on how local private initiatives may build stronger communities and vice-versa, in a mutually transformative relationship. The focus lies on an SE named Oficina de Agosto (OdA), which is a folk-art studio, school, and shop located in the village of Vitoriano Veloso. Other local social enterprises are also part of the study, emerging as a result and as co-producers of a new economic, cultural, and societal reality precipitated by OdA.

With the aim of showing the article's significance, this introduction will briefly place the study in a broad geographical, historical, economic, cultural, and theoretical context, will review the current state of pertinent scholarship highlighting its controversies, will present research objectives, and will summarize the principal contributions.

\subsection{The Context (and the Context of the Context)}

Discussing the context of the context [1] is fundamental to understanding the characteristics of place that set this specific SE to success. Additionally, it explains the non-extractivist approach to methodology, epistemology, and ontology we have adopted for this study. In reporting the historical developments that brought the context to its current configuration, we are following Askegaard and Linnet [1] in their call for explicit connections between the 
structuring macro-social historical frameworks underlying any researched phenomenon and the micro-social lived experiences of research participants.

Vitoriano Veloso is a 2000-inhabitant village, better known by its nickname: Bichinho (translating as "little animal", "small critter", or even "pet"). It is located in the Brazilian countryside state of Minas Gerais, which owes its name to the mining activities that ignited the region's occupation in colonial times and are still being conducted by giant corporations, with tragic consequences for people and the environment alike, such as the many dam disasters that occurred in the past few years [2]. The first maps that document Bichinho's existence and location date from 1777, associating its emergence to the Brazilian gold rush colonial period. Besides aurific extractivism, Bichinho's early economic and cultural life was marked by slavery, with half the village's population formed by black slaves; by religiosity, with the main Catholic church working as a symbol and locus of community congregation, control, and syncretism; and by women's relative protagonism, with many families reproducing the structure inherited from Northern Portugal in which a woman acted as head of the family, nevertheless under patriarchal norms [3].

The colonial period in Brazil was fuelled by Eurocentric economic drive and religious values, frequently spread in a violent manner. Indigenous and African people were enslaved and catechized as steppingstones of an extractivist and ethnocentric process of civilization whose main objective was to provide first sugar and tobacco, then gold and diamonds, and later coffee, to European commerce. This is how Brazilian society was organized for centuries since 1532 [4,5], sprouting a system of dualities with long-lasting and still-present consequences, such as the silencing and disenfranchising of subaltern groups. Some of those dualities were colonizer and colonized, human and sub-human, master and slave, superior culture and inferior culture, superior race and inferior race, man and woman, white and black, and white and indigenous [3,4].

Having been populated under the aforementioned dynamics of commercial gold extraction, in 1789 Bichinho was home to a revolution aiming at Brazil's independence from Portugal known as Inconfidência Mineira, whose main leader, Joaquim José da Silva Xavier (also known by a nickname: Tiradentes), was arrested, hanged, and dismembered, becoming one of Brazil's historical martyrs. For this reason, circa 1894, Bichinho was renamed after one of its dwellers who was part of the failed revolution: Vitoriano Veloso. However, the endearing nickname "Bichinho" resists until this day, with residents offering competing explanations for its origin. Some say the name "little animal" refers to a small lizard sculpted at the feet of the main statue in the village's Catholic church, officially called Nossa Senhora da Penha de França (Our Lady of Peña of France) but dubbed Nossa Senhora do Bichinho (Our Lady of the Small Critter) by villagers. Others say that "little animal" was a term adopted by plantation owners to refer to their slaves. One of our informants claimed he invented this explanation, with the original farmer being Vitoriano Veloso, to satisfy tourists inquiring about the village's nickname. A third explanation remounts to colonial times, when the village served as overnight board to travelling drovers who would be advised by locals to watch out for the "small critters" roaming the surrounding woods for food [3].

When coffee replaced gold as the main export product from colonial Brazil, and gold extraction came to a halt in Minas Gerais, Bichinho and nearby towns went through a long phase of depopulation and impoverishment that lasted for centuries. Locals subsisted from small agriculture, barter, and small commercial establishments, many of them run by women [6]. In the twentieth century, men migrated to larger cities in search for jobs at construction sites as a means to support their wives and children, who stayed behind in Bichinho and had to develop new coping strategies and abilities. The Catholic church of Nossa Senhora da Penha de França prevented the village from falling into complete oblivion because it attracted a mild flux of religious tourism. One of the survival strategies developed by local women was to sit outside their houses crocheting. Besides being a pastime and a socializing ritual among neighbours, it also became a source of income, as 
pilgrims took an interest in the crochet items those women crafted. Therefore, crochet was the first expression of folk art in Bichinho [3].

In 1993, there was little to no electricity in Bichinho, roads were not paved, and farm animals roamed freely along the main street that connects the town's Catholic church, built with simple architectural features to ward off possible burglars, to villagers' equally simple houses. That was the year when Antonio Carlos Bech (also better known by a nickname: Toti) arrived from São Paulo, fleeing big city chaotic life. In Bichinho, Toti started OdA as part of a sustainable development project first as a school then as a folk art studio and shop. From the beginning, he hired an all-local work force, comprised of those women who had stayed behind and taken care of the children, sometimes working as maids in nearby towns, and of the returning men, who, before OdA, had migrated to work in larger cities far from their families. Building on their previous experience as needleworkers and construction workers, Toti taught them how to make and sell folk art, furniture, and other local crafts, with motifs, aesthetics, techniques, and positioning that met Brazilian consumers' needs, especially wealthy ones in São Paulo. The most talented artisans went on to open their own studios, selling part of the production to OdA. Bichinho's first telephone landline was installed at OdA's headquarters. The same happened later with Bichinho's first Internet connection.

Due especially to OdA [3], Bichinho is now a bustling touristic destination with folk art commerce as its main attraction. Together with the increase of buying power in the 1990s and with a broader movement towards the creation of a national identity aligned with the concept of modernity, which valued folk art as a Brazilian asset [3], the aforementioned context of the context [1] created the conditions that concurred to OdA's success as a social enterprise and as a catalyst for community renewal. Further community transformations will be discussed in the Results section of this paper.

\subsection{Social Enterprises, the P.L.A.C.E. Model, and the Management of Paradoxes}

The term "social enterprise" can be defined as the use of non-governmental, marketbased approaches to address social issues [7]. In the United States and in Europe, social enterprises have become increasingly popular as a means of financing and providing social initiatives [7]. If a social enterprise follows the non-profit model, it may depend heavily on donations and on external investments, which creates instability and uncertainty about its continuity. Recent pressures on non-profit organizations to become financially sustainable through the introduction of commercial activities suggest that it is possible to position social enterprises on a continuum from purely philanthropic to purely commercial [8]. The social enterprises that are the focus of the present study are aimed at profit, but a considerable part of their revenue is reinvested in the community and in the business itself so that it can become sustainable and economically viable. Furthermore, these ventures arise from social and environmental motivations, which become an integral part of their business strategy [9]. That is, they do not distinguish their business strategy for commercial purposes from their sustainability strategy. Both are intertwined. Without social or environmental purpose, these businesses would not exist.

In recent years, researchers from the Memorial University of Newfoundland, in Canada, have studied regenerative organizations, arriving at five principles for community development, which, with the aid of local champions dedicated to the social, economic, and environmental well-being of Western Newfoundland, they organized under the acronym P.L.A.C.E. [10]. $\mathrm{P}$ is for "promoting community champions", $\mathrm{L}$ is for "linking insiders and outsiders", A is for "assessing local capacities", C is for "conveying compelling narratives", and $\mathrm{E}$ is for "engaging both/and thinking". As we shall discuss, this organizing framework helps us understand OdA's practices in Bichinho.

Going a step further, the same research team offers important suggestions on how to manage the paradoxes that emerge from the relationship between social enterprises and the places in which they operate [11]. During a seven-year study of Shorefast, a company deeply involved in social and environmental regeneration in Fogo Island, these 
authors created a second context-transferable model to help social enterprises faced with tensions that arise from the juxtaposition of the insider and the outsider, the old and the new, the traditional and the contemporary, the analogical and the technological, the local and the global, the rural and the metropolitan, and the social and the economic. Instead of understanding these contrasts as irreconcilable tensions that force either/or managerial choices, Slawinski et al. [11] recommend a both/and mindset, requiring time, patience, and meaningful exchanges that will, eventually, reveal the opportunities hidden in those paradoxes.

Paradox management literature defines "paradox" in organization studies as more than conflicting demands or opposing perspectives. Lewis [12] broadened the concept to include complexity, ambiguity, transformation, and plurality, calling attention to the opportunities that lie in surprising, seemingly absurd research findings. Paradox management became a way to foster change through the understanding of multifaceted, puzzling, counter-intuitive phenomena. She encourages researchers to seek out and try to explain anomalies, which might be more in tune with the paradoxical nature of individuals, groups, and organizational life, instead of trying to over-rationalize and oversimplify organizational complications. Paradox management literature thus defends that great insights might derive from the confrontation with intricate, interwoven, and apparently irrational contradictions [13].

One of the objectives of the present paper is to answer Smith et al.'s call [13] for more studies applying paradox theory in general, and, in particular, Slawinki et al.'s call [11] for more contexts in which their paradox management model may apply. As a result of the analysis of the OdA case under the theoretical lens of paradox management, we intend to provide practical recommendations that may help local enterprises create economic strategies and financial viability for the business, without losing sight of their social and environmental purposes.

Inner weaknesses and outer threats that might be troubling OdA and other local SEs emerged from in-depth interviews and from literature review. One outside threat reported by locals was the recent hijacking of folk art and craft products by larger visiting companies with no connection to place-a placelessness that denotes their lack of commitment to social and environmental regeneration. We would like to address that in our managerial recommendations. As for a possible solution to OdA's inner weaknesses found in scientific literature, we would like to juxtapose Slawinski et al.'s paradox management model [11] with Barbosa's critical anthropological analysis of OdA's current state [3], which she described as a divide "between the social and the capital". Barbosa [3] wrote a thickly nuanced ethnographic report on Bichinho's dwellers and their identities, dedicating part of the study to OdA's role in the village's social and economic revitalization. For Barbosa [3], the tensions arising from the clash between OdA's initial social purpose and its current economic purpose have brought the SE's regenerative power to a halt. By unpacking this controversy in light of paradox management, we would like to suggest ways of implementing both/and practices in Bichinho that may help move beyond Barbosa's [3] paralyzing either/or conclusion.

\subsection{Research Objectives, Significance and Main Contribution}

Further specific objectives of the present study are to analyze the catalytic role of the SE in revitalizing Bichinho economically and culturally; to discuss the local conditions that set the SE to success; to understand the importance of place, entrepreneurial ecosystems, local perspectives, and processes; to identify OdA's forces but also its boundaries, limitations, and challenges; and the aforementioned objective of providing managerial recommendations that may help entrepreneurs in Bichinho manage the tensions emerging from the juxtaposition of the social and the economic, the traditional and the contemporary, the local and the global, and the insider and the outsider.

Contrasting the previously described aspects of the context with the reviewed literature, we arrived at the following research question: what were OdA's place-based initiatives 
that successfully transformed the SE and the community, what are the current challenges, and what place-based lessons may help solve them?

Finally, we believe the significance of the present work also lies in its attempt to give voice to the Global South, a place of enunciation as important as any economically developed research context. In particular, we intend to shed light onto ways of knowing that have been historically silenced and subalterned, since Bichinho was born out of a colonial process of political and economic domination, employed with the objective of exploiting local human force and environmental richness for the benefit of the colonizer [3]. Our overarching goal is to offer a study of SEs with a non-extractivist approach to methodology, epistemology, and ontology.

The main take-aways of the present study are three-fold: (1) it illustrates how social enterprise may work as an alternative market model that could support community building; (2) it raises awareness to the possibility that social enterprises' initial social focus may not be perennial or unshakeable, in an undesirable change that might require a both/and mindset and a patient management of paradoxes; and (3) it offers practical managerial recommendations to the SE under focus, which might be extended to other local businesses, or to SEs in other semi-rural Brazilian towns, or even in international settings that might bear economic and social resemblance to our researched context.

In the next section, we explain our methodological design. The Results section provides a thick description of the phenomenon, organized under the P.L.A.C.E acronym. In the Discussion section, we first compare OdA to other SE cases found in literature. We then identify in Barbosa's study about villagers' identities [3] a useful insight for SE research: the possibility that an SE's initial social purpose might not be perennial or unshakeable. We proceed to point out that this author's assertion about OdA's current purpose is based on an either/or mentality. Instead, we offer an alternative view, based on paradox theory's both/and perspective, and we bring post-structuralism to the debate, in order to reveal the extra challenge posed by the Brazilian context with its long-lasting history of hierarchical opposing categories that lay underneath the opposing forces a place-based SE usually faces. We close the Discussion section pinpointing possible context-bound practices that could be adopted to overcome Bichinho's current predicament. Their underlying logic could be summarized as: long-term patience, non-hierarchical relationships, and a constant effort to practice both/and thinking until win-win solutions arise, such as those suggested by the adopted paradox management theoretical toolkit. The Conclusions section summarizes research objectives and contributions, mentioning limitations, and suggestions for future studies.

\section{Methods}

This project's research objects were the SEs that have generated community transformations in Bichinho, with particular focus on OdA. Research subjects were local social entrepreneurs, their former and current employees, and other village dwellers.

Fieldwork design combined ethnography and art-based research (ABR). Ethnography is a method originated from Anthropology that uses in-depth interviews and participant observation as data collection instruments [14]. Ethnographic studies are affiliated with the interpretive paradigm [15], adopting a qualitative approach [16] and an inductive perspective [17] towards fieldwork, which allows the emergence of unexpected emic cultural categories. In this case, we conducted data gathering and interpretation in a nuanced deductive-inductive way, with the P.L.A.C.E. framework [10], guiding (but not restraining) our ethnographic observations and reflections.

ABR combines the tenets of the creative arts in research contexts [18], employing artistic methods to gather, analyze, and/or present research data [19]. It is a processoriented methodological framework through which knowledge and meaning are built in a contextualized, interactive, reflexive, and co-created manner [20]. By taking on artistic practice as part of the scientific study, $A B R$ invites creative efforts not only from researchers but also from field participants, with communal art facilitating the expression of the 
phenomenon as it is lived by the individuals [21], and communicating emotional aspects of social life [18]. Because it creates connections among community, researchers, and audience, ABR has a transformative social and political influence on the individuals engaged in it [18]. It gives voice to marginalized subjects, it deepens researchers' interpretations, and it welcomes audiences' inputs.

In order to understand discourses, behaviors, and values, we have conducted 16 in-depth interviews and engaged in several ethnographic informal interactions [17] with actors involved in the production and consumption of goods and services offered by the SEs under study (see Table 1). The in-depth interview protocol was designed with the objective of understanding participants' experiences with OdA's and Bichinho's social aspects [17], and was guided by two questions suggested by Malinowski [14]: what participants say about what they do (discourses) and what they feel about what they do (values). To answer Malinowski's third question-what respondents actually do (practices) — participant observation has been carried out in loco in order to apprehend behaviors and to bridge the gap between practices and representations.

Table 1. In-depth interview respondents.

\begin{tabular}{cc}
\hline Respondent & Relationship with the Place \\
\hline Antonio Carlos Bech (Toti) & Social entrepreneur at OdA \\
Sonia Vitaliano & Business partner at OdA \\
B & Former employee at OdA \\
D & Former employee at OdA \\
H & Former employee at OdA \\
M & Former employee at OdA \\
AL & Former employee at OdA \\
C & Employee at OdA \\
AD & Furniture designer and occasional collaborator at OdA \\
I & Friend and former event planner at OdA \\
Angela & Entrepreneur in Bichinho \\
Fábio Mattioli & Entrepreneur in Bichinho \\
Alexandre Tabaroa & Entrepreneur in Bichinho \\
Peter Fedewicz & Former entrepreneur in Bichinho, currently in Tiradentes \\
Fernando Paulo Dias & Former entrepreneur in Bichinho, currently in Tiradentes \\
Ted Dirickson & Entrepreneur in Tiradentes
\end{tabular}

For the first eleven interviews, conducted in March and April 2019 by this article's first author and by Dr. John Schouten (who is also a member of the research team), interview protocol focused on oral histories [22] and comprised questions about the participant's experiences with OdA and with Bichinho. In March 2020, the second author joined the team, visited Bichinho, and suggested the ABR approach to data collection and interpretation. After that, two projective exercises [23] based on the autodriving technique [24] were added to the semi structured interview script, which was then applied to five more respondents, all former OdA artists.

In autodriving [24], visual stimuli previously created by respondents are discussed during qualitative interviews. These stimuli can be photographs, video footage, a personal diary, or, in this case, self-portraying sculptures made by the respondents upon researchers' request. Projective responses can also be elicited by stimuli that were not produced by the respondents, such as photographs published in traditional or social media [25], movie trailers [26], videos created by researchers specifically for the interview [26,27], or, in this case, a coffee-table book. By encouraging participants to talk about what is portrayed in visual stimuli, and not directly about themselves, the objectives of projective techniques are to facilitate the discussion of sensitive topics; to penetrate beyond respondents' level of awareness; to circumvent barriers when there is difficulty to admit incapacities, weaknesses, addictions, fears, or prejudices; and to obtain data in greater quantity and depth 
if respondents have poor memory, little knowledge of themselves, little propensity for self-disclosure, little verbal articulation, or great shyness [23].

With those underlying premises, the first projective exercise invited participants to comment on a highly illustrated coffee-table book about OdA, published years before [28], which contained several employees' quotes and photographs. During in-depth interviews, we invited participants to take their time browsing the book, and then inquired about their memories regarding its production phase, when the information and images in the book had been collected. We also asked respondents to describe what was depicted in their most favorite and least favorite photographs in the book. The objective was to tap into feelings and emotions from past and present moments, without confronting participants with direct questions about how they felt.

For the second projective exercise and as part of the ABR approach, we commissioned from six former OdA's employees a tridimensional self-portrait. These specific artists were suggested by Toti, who worried about their lack of income during the pandemic of 2020, since they were no longer in OdA's payroll. The artists received half of the agreed payment upfront, and the remaining sum upon delivery of the sculpture two months later, when they would be interviewed by the first author. Five of them finished the assignment and one dropped out, no longer responding when contacted. The sculpture was used during the interview as a trigger for identity discussion, working as a third party onto which respondents could project their views and meanings about OdA, about Bichinho, and about themselves.

As a trial-and-error process that mirrors what Arsel [17] (p. 940) has called "the iterative research circle", the ABR aspects of this project are still ongoing and will, if all goes well, bring about new insights after the present article has been published. We will invite more artists to create tridimensional self-portraits in hope their artwork will precipitate deeper identity discussions during future interviews, and we will exhibit an installation made up of all the self-portraits as a later part of this project, in order to open gaps for discussion [29], instead of zeroing in on specific scientific answers [21] to our research questions, which is one of the beauties of ABR.

Field data gathered so far have been analyzed in four steps: transcription of interviews, cross-sectional thematic analysis, descriptive analysis, and interpretive analysis [30], with the ultimate goal of generating theory, in addition to offering a thick description [15] of the phenomenon.

Cross-sectional thematic analysis consists of coding participants' discourses, through the detection of recurring themes, either in light of analytical categories previously found in literature, or in an unexpected fashion, with the emergence of native categories. This means that the themes identified as relevant were chosen both a priori, due to pre-existing theories and frameworks, and a posteriori, due to the inductive approach to fieldwork. This interpretation stage generated semi-raw textual data, transversally organized by analytical categories and native categories, and no longer interview by interview [30]. The codification and reorganization of data went from an "approach focused on the coherence of each individual (...) to a transversal approach focused on thematic coherence" [30] (p. 123).

Once the cross-sectional thematic analysis was completed, the descriptive analysis began. In addition to the data collected via in-depth interviews, at this stage, the data from observation sessions, that is, photographs, videos, and field notes, were also examined and described. Alami et al. [30] (p. 123) emphasize that "a description is not a simple enunciation of elements one after the other". For these authors, it is important to identify and understand the connections between elements, revealing underlying social structures. Therefore, this interpretation stage was responsible for originating thick descriptions [15].

After the completion of the descriptive analysis, the interpretive analysis began, which sought to strongly articulate the categories and descriptions elaborated in the previous steps with the theoretical toolkit adopted for this study, aiming at inferences, conclusions, and new theoretical proposals. 


\section{Results}

OdA is located in a beautiful acreage on Bichinho's main street. It is one of the first constructions one will see when coming from Tiradentes through the $7 \mathrm{~km}$ scenic and bumpy road that links the two towns. Tiradentes is the 7000 inhabitant touristic town where most visitors lodge when coming to Bichinho. On the left-hand side of the road, one will find OdA's shop, a large rustic house currently painted in pink, with green doors and windows. On the side of the house, a dirt path surrounded by vegetation leads to Toti's acreage, where a showroom, a few studio sheds, and living and communal quarters are located, all very rustically built. Toti used to live in the acreage, but now resides in a gated community in Tiradentes. One current and one former employee, Celia and Marcello, occupy two of the houses in the acreage. They have both worked at OdA for decades, with Celia referring to Toti as "papi", to which he jokingly replies "I have no old kid like you".

Toti runs OdA with his sister, Sonia Vitaliano, who is in charge of broader management and financial activities, based in their OdA store in São Paulo, where the family is originally from. For many years before coming to Bichinho, Toti owned an antique store in the vicinity of São Paulo, with a significant network of providers and buyers. He used to visit Tiradentes and Bichinho, sourcing items to sell at his store. When he decided to flee the big city, his initial plan, as he told us during his interview, was to start an arts and crafts traveling workshop. He tried it out in a beach town near São Paulo, before finally deciding to move to Minas Gerais:

I wanted to stay three years in each town. To teach, and to leave towards the South of Brazil. But in beach cities, they're not in need of arts and crafts. And there are no raw materials. Here, there were raw materials and people willing to work. ( . . ) We would scavenge in the woods. (...) This was a project with no funds. ( . . ) We never had any [financial] support by the municipality or the government. (... ) We gathered things lying around. Wood, old tins, old glass, fabric. (Toti, social entrepreneur at OdA)

OdA started, therefore, as a workshop in the month of August, hence its brand name. Toti's traveling plans changed, as he settled in Bichinho, with a stationary school at first, followed by the shop initiative. This is how he described his teaching objectives:

Our project has to do with income generation. You don't just teach them a technique. You teach them how to make a product that is sellable. They must be able to make money. There's no use in teaching them papier-mâché so that they will all sculpt the same little doll. (Toti, social entrepreneur at OdA)

Work at OdA is a collective effort that starts out of Toti's imagination. The first input for a piece always comes from him. Different people will work on different production phases of the same piece: preparing the reclaimed material, sanding, welding, painting, finishing it, and finally selling. The execution process welcomes participants' creativity, but Toti always supervises the end product. A former employee who already had an art background when hired by Toti in the 1990s retold how it all works: "Toti would tell me his thoughts for a new piece and I would draw them down for the team. And everything that is produced is done by the hands of several people". Another former employee stressed the freedom inherent to the process and its social outcomes: "Toti gives a lot of freedom to his employees. We would get paid to learn. Toti values the human being. You would evolve. You would be able to buy something better for your kids". However, another former employee implied feeling deprived of her authorship in the creative process:

[At OdA], we did not sign our name on the pieces. That is, they did not belong to us. They belonged to OdA. ( ... ) Not even the larger pieces. We were not allowed [to sign]. ( ... ) Once someone commissioned a very large ostrich from OdA. So Toti bought the base made of wood, and D. and I sculpted it. The head. The parts. The feet. And then, this guy who only gave the wax finishing decided to sign it. I went ... "Nah, I'm not letting this pass. That is just too much. You 
did not make it. You just coated it with wax. And the piece is yours?" Toti made him remove his signature. (Former employee at OdA)

We were able to observe a few recurring themes underlying OdA's artwork: the "exvoto" (a votive offering to a saint, usually in return for a cure or miracle, which may be a painting depicting the miracle or a wax model of a healed body part.); the baroque arts and architecture style from Minas Gerais, which is central to Brazilian colonialism; ancient and Catholic liturgies; archetypical events, such as the Flood; fantastic chimeras and wings; the circus and ballerinas; robots; syncretism and miscegenation; the sea; tropicalism with its fauna, flora and fruits; social and environmental causes; and the juxtaposition of the sacred and the profane. A former employee explained the extent to which new themes impacted social life and culture in Bichinho:

Toti liked to add sex to the small sculptures [that go on a larger piece]. "Draw a little line here, to show it's a girl. Put breasts on her. For the boys, draw a small wiener to the side." People in Bichinho were very simple-minded, rustic people living in the middle of nowhere. So, for them, that was absurd. But they got used to all of it, to the whole sexuality business. I think this broadened horizons for people who had always been so belittled. So they started drawing breasts, willies, minnies. And that stopped being a stigma. So it was a taboo breaker. (Former employee at OdA)

When the same former employee mentioned human diversity as an important part of Toti's imagery, we immediately thought of one of OdA's pieces seen in their store in São Paulo, which depicted Syrian refugees being welcomed by the Brazilian population. The informant added: "And a demonstration of respect. Respect for the human being. Because we are all different. We are born with differences. So Toti asked 'draw a bald one, put hair on the other one, put a beard on this one'."

Artists at OdA work with reforested or reclaimed wood, metal, pigments, crystals, and found and repurposed objects. Society's waste is welcome there and regarded with good will. Piles of raw materials clutter different parts of the acreage where the studio sheds are located. "There's an ecological conscience to everything that is made", a former employee observed. "All products are based in recycling, in repurposing. At Oficina de Agosto, a small piece of metal becomes a leaf for a flower bouquet. So, there's respect for the environment. We encouraged people to plant their own gardens. Plants produce oxygen, and also because of the aesthetics".

OdA has seen more abundant times, having now 21 employees in its payroll, a number that used to be much larger in the late 1990s and early 2000s, as Toti described: "There used to be 60 to 70 people working here. It was a good time to sell in Brazil". One of OdA's earliest employees, who went on to open his own business, recounts what he would see from his studio window at lunchtime:

It was impressive, at 11 o'clock, mid-day, we used to see around 60 people passing by to have lunch in their homes. Because [there were too many employees and Toti] could no longer cook lunch for all of them. So, everybody would go home for lunch. We used to see 60 people leaving Oficina de Agosto [at lunchtime]. You don't see that anymore. (Former employee at OdA)

After the world economic crisis of 2008, OdA's large-scale sales and high prices started to decline. OdA lost many of its organizational customers, such as two of our research participants, who used to own a home decor store in Miami and bought from OdA by the bulk. In 2008, they closed their store, lost the mortgage to their home, and moved back to Brazil. Their destination: Bichinho. They opened up a bar right across the street from OdA's shop because, as frequent customers, they knew there was nothing to drink nearby and OdA's upscale clients could be interested not only in quenching their thirst but also in sipping a few premium vodka cocktails while taking a break from shopping. Their account goes like this: 
We started [our bar] in Bichinho in March 2010. ( . . ) We came back from the US after living there for 22 years. ( . . ) We came back after the crisis. We knew the area in Bichinho way before. We had a store for five, six years. We used to come to Brazil and buy stuff. We bought from Oficina a lot. (... ) The trucks would come there and stop. And fill it up. Oficina was our main supplier. ( ... ) It was the time of the recycled, the organic, so it was a boom in the US. We had five stores. (... ) The reason we came back was that, all of a sudden, the US crashed. ( . . . We decided to go back [to Brazil] but São Paulo, where we're from, was out of question. So, we visited Oficina and there was a place to rent right across the street. We always thought it was ( ...) something that people needed there, some place to have a drink, to have coffee. ( . . . ) You had to go all the way to Angela's just to have a Coke. ( . . ) There was this small place to rent. [We asked] how much is it [per month]? And it was something like 50 bucks, so cheap. Because Bichinho was nothing. Nine years ago, not so long ago. ( ... ) Toti changed that place. People would go to Bichinho just for OdA. (Former entrepreneur in Bichinho)

This is just one tiny example of the many businesses that were born and benefited from OdA's presence in Bichinho. At the time of Toti's interview in 2019, OdA had one single organizational client left, also a home decor store in Miami, which was paying for the majority of OdA's costs. But Toti was optimistic and felt that things were getting better.

We now turn our attention to the P.L.A.C.E. framework [10] in an effort to organize a thick description of the phenomena found in Bichinho. We then proceed to compare OdA's case to other SEs and to suggest ways of overcoming the social/capital paradox denounced by Barbosa [3].

\subsection{P Is for "Promoting Community Champions"}

The first principle for community development described by the P.L.A.C.E. model is "promoting community champions". A community champion can be defined as "an established and trusted community member with a good track record and a (confirmed) entrepreneurial interest, acting as the community access point ( ... ) for the facilitation of services and products into-and out of - the under-serviced community" [31]. New champions should be identified and supported by more experienced champions and by the community itself [32]. This might hint at a possible solution for Bichinho's current conundrums.

For the past thirty years, Toti has definitely been one of the most active and recognized community champions in Bichinho. During observation sessions at OdA's acreage, in one of the sheds that house a multitude of scattered materials waiting to be repurposed, a small framed drawing hanging on a distressed pilar caught the first author's eye. It was a drawing of a man with black hair, on top of which read "Toti, the patron saint of Bichinho". Upon inquiring about the drawing, the first author was informed that it had been made and gifted to Toti by a friend. Curiously, Toti decided to, in a nonchalant and perhaps modest fashion, hang it in a shed, among piles of unfinished or scavenged stuff, instead of displaying it in his home. In its littleness and simplicity, the drawing carried a powerful message that confirmed and projected Toti's community champion status, lifting him to a place of holiness.

The mixture of the sacred and the profane is a recurrent underlying logic in OdA's works that mirrors Brazilian religious syncretism, an early (and still current) form of resistance to and accommodation of Catholic colonialism by indigenous and African people, who had their own beliefs and spiritualities, apart from Portugal's impositions. In Bichinho in particular, Barbosa [3] found that Catholicism was accommodated by lay organizations, made up mainly of women, giving rise to traditions, rituals, festivities, and gatherings around the church of Nossa Senhora da Penha de França, with motivations that were not strictly religious.

One of our informants emphasized how art championed by Toti was capable of renewing this community: 
People used to grow fruits and vegetables and barter them. They would only buy the essentials. And with art, other opportunities came along. People improved their houses. Their entire quality of living improved. And all that was provided by Toti. Not just in Bichinho. All the other towns around benefited from it too. (Former employee at OdA)

From a macro perspective, Toti's arrival and practices gave rise to a new economy in Bichinho. From a micro perspective, Toti, as a community champion, helped the individuals that came in contact with him, from paying for their health treatments to literally driving them to their doctor's appointment. One former employee remembered: "Toti would build bathrooms at peoples' homes. He taught people how to brush their teeth. He would pay for their food". Another former employee recalls:

One of the first things Toti did was to send people to the dentist so that they could smile. So that they could be themselves. This is fundamental. To raise people's self-esteem so that they can work happily, so that they can burst into laughter. And work gets much more fun like this. (Former employee at OdA)

Toti is known for hiring people living with vulnerabilities. A friend of Toti's told us that, when OdA first started, Alcoholic Anonymous meetings were places where Toti would go to recruit local workforce: “Once, Toti said to me: 'let's go to AA meetings because we'll probably find people there who will want to work with us'". During his interview, Toti praised his best employee: "My best employee came from APAE [an association for people with cognitive impairments]. Him and his mother. He's very shy, difficult to talk to. But he's one of the best that ever worked here".

LGBTQ+ people are also welcome and very present at OdA. One of our research participants, a lesbian woman, told us how meeting Toti made her feel safe from the dangers of being a homosexual in the town where she used to live:

My family's reaction to my homosexuality was very serious. They asked me to leave the house. I was 16 years old. So [meeting Toti] changed everything, (... ) always helping his friends, always putting us (.. ) in a position of respect. (... ) So, with Toti, we had our gang. We no longer needed to go to the ghetto. Because when that happens, when your family abandons you, you go to the ghetto. And then you are exposed to everything. Drugs, prostitution, theft, dealing, everything. In São João Del Rei there are a lot of ghettoes. ( . . . ) I could be dead by now. I would not have survived in São João Del Rei. I could have died in an accident, or from drinking. ( . . . ) I've had my beverage laced without my knowledge [for example]. Because I was so young, I didn't know anything. And Toti is concerned about everyone having a home. So [he encouraged us]: "build your own house". I'm not just talking about financial aid. I'm also talking about ideas. Because he also has an entrepreneurial spirit, in addition to his artistic side. (Furniture designer and occasional OdA's collaborator)

She was not the only participant who revealed that Toti helped her dodge death. Expressions of gratitude permeated our respondents' accounts. A former employee who used to work as a truck driver before OdA and currently thinks of Toti "as a brother" testified: "I'm most proud of having won over alcoholism. Work [at OdA] took me off alcoholism. What Toti gave me is much larger than money. I believe I would be dead a long time ago if it weren't for Toti. I haven't had a drop for 25 years".

As for other community champions, from our interviews and from Barbosa's work [3], we understood that feelings towards religious and governmental leaders in Bichinho are ambivalent, as we will discuss next. In our respondents' discourses and during observation, we identified other entrepreneurs as community champions, especially Angela, who owns the busiest restaurant in the village. Long-established and new-coming distillery entrepreneurs might also be seen as community champions, but not without controversy.

Barbosa [3] collected data that conveyed feelings of estrangement and irritability towards the town's priest, even from research participants with a Catholic lifestyle and 
high religious involvement, who perceived him as an outsider and perhaps authoritative manager of the sacred. Some informants resented what they understood as a contradiction between a sacred sphere, associated with love and charity, and an economic sphere, materialized in the fees charged by the priest to perform masses or speeches at funerals, for example, reproducing, as Barbosa [3] puts it, exploitative power relations between the colonizer and the colonized. The author stresses that this phenomenon is not of fully-fledged antagonism or resistance to the Church as an institution or, in our case, to its mediator as a community champion. Her informants acknowledged the importance of a religious leader, as long as he fits into certain dynamics that do not promote subalternity. They recalled a previous town priest who "spoke like locals speak" and was therefore widely appreciated, but who, in their minds, was relocated to a distant parish precisely because he used to encourage Bichinho's residents to get organized and demand fairer prices for religious services.

Regarding governmental leaders, our research participants expressed a sense of skepticism. Bichinho is one of the many districts of a municipality called Prados. A previous mayor of Prados was born in Bichinho. However, we were told that he has not done much for his place of birth, either socially, economically, or environmentally. One of our informants concluded: "no politician has ever done for Bichinho what Toti has done". Another interviewee explained it in more detail:

A big problem we have now is that (... ) we don't have laws that protect ... that say what is allowed, and what isn't allowed. (...) People do everything wrong. For example, [formally] these are rural lands. So, there shouldn't be lots to rent [commercially]. Therefore, you can't have legal papers. So, everything that is done is done informally. Light is a workaround. Water is a workaround. Everyone builds what they want. ( . . . ) In rural areas, you don't have great supervisory power. Because nobody wants to inspect. Everyone is blood-related. So "Am I going to inspect [my relative]?" ( ... ) And look, we managed to have a mayor here [born in Bichinho], who had worked [at Oficina de Agosto]. He couldn't do much about it. He did something, pavement, but not much. (Entrepreneur in Bichinho)

When we interviewed Angela, who lends her name to her restaurant, Tempero da Angela, we were told to meet her at the town's church in a weekday morning. She had spent hours there cleaning the church, a chore she performs regularly. Angela started her restaurant in 2003, focusing on OdA's clients who could not find a place to have lunch in town. Today, Tempero da Angela attracts many tourists that usually line up outside its doors, patiently waiting to be seated. She offers typical dishes from Minas Gerais, in a self-service operation, with people scooping red beans, pork meat, and poultry with okra, to name just a few, directly from large rustic pots that sit on two wood-burning stoves. Angela works in the kitchen every day and will gladly fry eggs for the customers who approach the kitchen door and ask her to do it, sunny side up. Outside the window, we see the vegetable garden and orchard from which much of the greens served in the restaurant come. Angela was able to send her children to college with the success of the enterprise she had started in the back of her house, like many other businesses in Bichinho. Her concern with education spreads to her employees and she likes to help them go back to school:

My daughter was Bichinho's first university student. After her, came many others. (... ) There is a boy who worked with me. He went to college to study biotechnology, I think. It didn't work out very well. Then he studied odontology and is now working in Campinas. (... ) It will take many years for him to pay us back [the student loan she gave him]. Besides the [moral] support. ( ...) Studying is fundamental. I always encourage kids to study. (... ) There is this guy who teaches guitar to the kids, I've been sponsoring him for seven years. We try to do these initiatives to get the kids off the streets. (Angela, entrepreneur in Bichinho) 
Angela's story is not the focus of the present article, but it is important to unveil her potential as a community champion. She also told us about a community effort to clean the village in the 2000s, which included local entrepreneurs and residents:

The English couple [who lived in Bichinho] helped a lot. The people from Cachaça Tabaroa, who are not [originally] from here but were already here. Toti and Celso. Rodrigo from the Automobile Museum. First, we started a movement because there was no garbage collection here. So, the street was full of scattered garbage, the back yards, everything. So, we started holding meetings to inspect what was being done right, what was wrong ... And our first initiative was to deal with the garbage. We promoted a week of garbage pick-up. Everyone adhered. Each person was asked to clean their yard. And the companies that were already in Bichinho, with few workers, were responsible for cleaning the streets and vacant lots. We paid for a truck to take it all away. I don't remember how many truck pick-ups there were, but I believe more than twenty trucks of garbage were collected. ( . . . ) Then we looked at the problem of basic sanitation. We even went far. But then the project ended, it didn't work out. It was quite frustrating for us. Because we managed to get a biodigester to collect sewage. But then the City Hall didn't follow through. But the garbage issue was something we managed to solve, right? Today you walk around town and you don't see any garbage. We managed to raise awareness, on the streets, at school, at home. There's one or two that still litter, yes, but it's hardly anyone. Nobody throws waste in the water streams anymore. There's always someone watching, someone who puts up a little sign. (Angela, entrepreneur in Bichinho)

However, as we have been told, sewage still goes into the water streams, since the biodigester project was abandoned:

There's an old social center in Bichinho, like an NGO. ( . . ) If someone shows up, wanting to manage the business diligently, it's possible to achieve a lot. For example, the sewer here. It would be very easy to at least collect the sewage. But it doesn't happen. The sewage is all thrown into the river. ( . . ) With so many people coming to live here, it seems that they created a rule that, to be president [at the social center], you cannot be an outsider. (Entrepreneur in Bichinho)

As the previous quotes imply, promoting community champions is a task that, in Bichinho, has required the management of tensions between outsiders and insiders, as we shall discuss in the next section. The community efforts described by these informants also show how social initiatives usually require an interactive network of players, usually formed not only of individual town dwellers, but also of social enterprises, governmental and non-governmental organizations, and even traditional businesses.

Bichinho is home to at least three distilleries that produce the typical Brazilian sugarcane aquavit named cachaça: Cachaça Velho Ferreira, Cachaça Tabaroa, and Cachaça Mazuma, the latter being a relatively new initiative from a retired businessman that decided to move to Bichinho a few years ago. A visitor at the Mazuma headquarters can take a tour through the sugarcane crops, the zero-waste gravity operated production facilities, the wood-barrel aging cellar, and the shop. Despite aiming at sustainable, environmentally conscious operations, Mazuma is not regarded with good will by some locals, who see its entrepreneur as an outsider that has already been fined for inadequate use of the land. As one of our informants put it: "I have lived here for twenty years, but I am still considered an outsider". These distilleries' stories are also not the focus of the present report, but their owners, despite current controversies, may display the potential to act as community champions. One of these entrepreneurs manifested concern about the lack of dialogue between commercial and governmental actors in Bichinho:

I fear a lot for the future of Bichinho. Because we don't talk about working together, about choosing the target audience together. This business of allowing anyone to show up and open any sort of commercial activity ... (...) I think 
it's too risky. ( . . ) I think there should be a partnership between the public and the private sectors to try to protect these things. But I don't see any sign of this happening. ( ... ) And the University here could do a community project. We could make a partnership. To protect the ruins from the colonial period. To identify the trees, for example, perhaps we will discover a lot of things. And then, with the support of the University, which is a federal agency, we might be able to talk to other agencies that may protect Bichinho. No need to take away someone's land. [Show them that] 'you can make money out of this. So, stop destroying it.' These initiatives are missing. But with this crisis ... (Entrepreneur in Bichinho)

While we acknowledge that Toti's role as a community champion is undisputable, we found no evidence that this social entrepreneur or that his social enterprise may have been identifying and promoting more champions, other than the training of instructors to travel and teach arts and crafts outside Bichinho, as described by Toti himself: "We train teachers to go to other cities and do workshops. They already get there with a [commercial] project [in mind]. Teachers from OdA have visited around 50 to 60 towns". Despite being an initiative to promote champions, they do not work locally, and their championing stays restricted to income generation through folk art, not spreading to other community needs.

Therefore, thinking of community champions as a fundamental principle for community development, our managerial recommendation would be that the same efforts Toti has shown to transform his apprentices into autonomous artisans with their own studios be applied in the promotion of other community champions among OdA's current and former employees. As we have discussed, power relations are critical in the identification and action of these agents. Community champions in Bichinho must not reproduce a hierarchical structure that subalternates locals. Long-established and new-coming entrepreneurs with a social and environmental conscience may formally unite for a common good based on place, organizing meetings and actions that include residents (not as targets but as project cocreators) and all types of businesses (not as competitors but as partners that will all benefit from a stronger community).

The tensions that emerge from the encounter between insiders and outsiders are not irreconcilable. These paradoxes might, on the contrary, produce opportunities, if carefully managed, as we shall discuss next.

\subsection{Is for "Linking Insiders and Outsiders"}

Place-based SEs can greatly benefit from the contact between outsiders and insiders. Knowledgeable insiders (such as local volunteers, municipal government representatives, business owners, and other town dwellers) help outsiders (such as visiting artists, industry experts, media, and academics) understand cultural nuances of place [33]. Outsiders may bring new skills and new ways of looking that help insiders shift perceptions about a place they might be just too used to [34]. Literature and practice in different cultures have shown, however, that this is not an easy encounter [35].

OdA's and Toti's biographies in Bichinho form a rich illustration of how linking insiders and outsiders might work as a second fundamental principle for community development. Toti was an outsider who arrived with a purpose of working collectively with Bichinho's insiders, and that is one of the main reasons for his enterprise's success. He went on to being a catalyst for matching more outsiders with insiders, as he connected his former customers from São Paulo with Bichinho's arts and crafts producers. Our own incursion as researchers, and others' that came before us, are also evidence of Toti's power to connect outsiders with Bichinho's insiders.

When Toti arrived in Bichinho, besides crocheted crafts made by women, there were other local artisans practicing a limited conceptual and aesthetical repertoire. Sculptures usually depicted animals, especially the lion, following a tradition created by local families Andrade and Julião. Furniture design copied classic French and Portuguese styles. Toti sparked new design ideas inspired by local rural motifs that celebrated native characteristics 
of the place and, at the same time, were valued by his former customers in São Paulo. For example, instead of the traditional wooden lion, many of OdA's pieces portray guinea fowls, which are very common in Bichinho. A furniture designer and occasional OdA's collaborator explained how Toti did it:

He exalted, in art, the place's identity. ( . . . ) Before, we kept copying João VI chairs, Louis XV chairs, Marie Antoinette cabinets ... [The design style was] always very imperial, colonial. ( ... ) He branded that little flower that the artisan had already been making and which had no value. (... ) He transformed handicraft throughout Brazil. All furniture and objects made of iron and wood nowadays [in Minas Gerais], they all came from Toti and Celso. (Furniture designer and occasional OdA's collaborator)

She was referring to the large furniture and handicraft industry present in many cities in Minas Gerais, especially those around Bichinho, such as Tiradentes, São João Del Rei, and Santa Cruz de Minas.

Toti has also promoted the exchange between outside artists and his local apprentices: "I used to invite renowned artists from São Paulo to come stay here. They would stay for a few weeks, they would also teach the kids. To have something different for the kids. So, the guest house here is precisely for that".

Although there may be a general resistance to outsiders in Bichinho, the town has shown that an outsider that truly empathizes with the insider is embraced by the community. In one of our interviews, we learned that:

Toti has no prejudice. If an ex-alcoholic relapses, Toti prefers that they come in to work. Toti asks 'you're not going to cut your finger on the saw, are you? If you're ok to work, so come in'. He prefers the person nearby. He takes care of everyone. He doesn't forsake anyone. If someone has a problem with the law, they turn to Toti. And everyone wants to protect Toti in return. They are even a bit overprotective of him. (Furniture designer and occasional OdA's collaborator)

So, although there may be resistance to outsiders, if they do not reproduce a hierarchical power structure that subalternates locals, the chance for a true two-way exchange increases.

One possible suggestion to force the encounter between outsiders and insiders, triggering tensions and, therefore, opportunities, could be to house, at OdA or at other local institutions, artistic residency programs, with mid- to long-term stays, such as the ones promoted by the Haudenschild Garage [36], the InSite Foundation [37], the IDEAS XLab [38], and so many other privately funded initiatives.

\subsection{A Is for "Assessing Local Capacities"}

Like mentioned before, Toti helped broaden the artistic repertoire in Bichinho by directing artisans' attention to the natural beauty of the place. Local resources can be of environmental, physical, intellectual, social, or institutional natures [39,40]. A third principle for community development would be to identify and foster these previously taken-for-granted capacities.

As Barbosa [3] thoroughly describes, OdA found fruitful ground in Bichinho, was capable of building on local capacities and needs, and benefited from a larger project that embraced folk art as one of the country's cultural assets, during a time of overall financial prosperity. Women in Bichinho already knew how to knit, and men had construction abilities learnt from their work in larger cities. They all longed for family reconnection, and the work that Toti offered allowed men to return to their wives and children. A friend and occasional event planner for OdA described how Toti used to encourage locals to come learn new skills and work with him, boosting their confidence in what they already knew: “Toti used to ask the locals: 'what can you do?' If the person answered: 'I know how to install doors', Toti would reply 'so you know how to make picture frames. And if you know how to make picture frames, you know how to paint pictures. If you know how to 
paint pictures, you're an artist". We heard similar accounts from different interviewees during fieldwork.

Toti, himself, told us how he approached local capacities, of which Bichinho had plenty:

It all started with people coming by, looking for jobs. And I would ask "what can you do?", [they would reply, for instance] "Embroidery". ( . . ) In this village, almost everyone was born here. So, they know how to embroider, they know how to grow vegetables, they know how to make shingles, they know how to build a house, they know how to do everything. Because we're in the middle of nowhere. Well, it used to be far from everywhere. ( . . ) There was no transportation. The bus used to come once a day. ( . . . ) So it wasn't difficult to start the project here. It was well accepted. First thing: the community accepted it. ( . . ) The gardener working here, I would look at his work and think "this guy is an artist". So, I went up to him and asked "do you want to be a woodworker?". Now, he is the best woodworker ever, he can make anything. ( ... ) We have an [artisan] here who used to be a bricklayer and nowadays he does embroidery. (Toti, social entrepreneur at OdA)

However, not everyone managed their transformation into successful artists well. Out of the many that went on to start their own businesses, some were taken by surprise with the financial results of their work: "For example, this boy who does this thing here, he used to ship containers [filled with his work] to the US. But then, just imagine, the young guy here in Bichinho, without any guidance. The family without any guidance. All of a sudden, there were dollars in his bank account. He spent it all on cocaine".

With that as a cautionary tale, the question that becomes evident is "what are other underused capacities in Bichinho that can flourish with a fresh perspective? Are there underused institutions, buildings, equipment? How do we identify and help flourish their potentials, while preparing them to deal with success?". One of our field participants mentioned local ruins from the colonial period that are currently being ransacked, instead of being preserved or restored to become touristic attractions:

[Showing photographs] these are signs of the gold colonial period. I think geotourists would be interested in seeing this. But this is deteriorating. (... ) For example, they used to make tanks out of stone to wash the gold. They used to make vaults, to keep gold and diamonds safe. The walls are as thick as this table, and eight meter tall. ( . . . ) There are many ruins here. They are all taken for granted. (... ) Now people are stealing those large rocks. (Entrepreneur in Bichinho)

More local capacities could be identified and assessed with the help of new community champions, organized to promote encounters between insiders and outsiders, which may shed light onto latent local assets and strengths.

\subsection{Is for "Conveying Compelling Narratives"}

Van Laer et al. [41] posit that people need narratives to make sense of the world and of personal experiences. When these narratives are positive, they may help boost self-worth. Diochon and Anderson [42] argue that narratives explain and communicate values, which, in turn, shape practices. Individuals and communities faced with long-term challenges may engage in fatalist and self-deprecating narratives [43]. Therefore, it is important for place-based SEs to find and share positive stories about the community and its people, focusing on abundance instead of scarcity, in order to shape constructive practices.

As a research team, we were fascinated by the stories of transformation due to the help that Toti offered to local people regarding not only their homes and families but also their physical and mental health. However, when we presented him with our preliminary findings, we were taken aback by his request to suppress or reframe certain stories. Not because they were not true, but because we had framed them as stories of scarcity. For Toti, telling stories about what Bichinho's residents did not have before his arrival may 
be embarrassing to them. The request was transmitted to us by a friend of Toti's, who explained his stance towards life in general: "He is a person that always focuses on the positive side of things. Nothing good can come from emphasizing bad things from the past. ( ... ) There are more important things to be said than that. (... ) Toti prefers to say that OdA contributed to locals' dignity. To women's empowerment".

After that request, we noticed how OdA's works that are themed with social and environmental causes usually focus on the solution, and not on the problem. For example, pieces that speak about pollution or racism do not include these words, they include terms such as "breath", "adopt", "hope", "silence", and "we are all siblings". Toti wants to tell compelling stories, trying to avoid self-defeating narratives. Another illustration of that was brought to us by a research participant who described art pieces created by Toti to celebrate the days that precede Easter Sunday, known in Brazil as "Semana Santa", an important religious holiday particularly in Minas Gerais. Toti created a series of installations entitled "O Descanso" (translating into something like "The Relaxation"):

He bought a bunch of crucifixes and took Jesus off the crosses. He positioned Jesus sitting on a sofa, with his arms spread wide against the back of the sofa. He cut Jesus at the waist, and laid him down in a bathtub, arms outstretched on the sides of the tub. That is, he took Jesus out of the representation of suffering [into a representation of relaxation or enjoyment]. ( . . . ) The priest in Tiradentes prohibited the exhibition of the pieces during Semana Santa. He said it would be sacrilegious. (Furniture designer and occasional OdA collaborator)

Among the many edifying biographies we encountered during fieldwork, there were accounts of not only mental and physical health improvements but also of financial prosperity that contributed to the overall well-being of specific individuals and their families, such as this one:

My life changed 200\%. Toti helped me be recognized [as an artist]. Customers that arrived at Oficina de Agosto were sent here by Toti. "Oh, there is this former employee that does this sort of work, go there". And I used to sell to Toti, and Toti sold to other people. Then I started selling on my own. ( ... ) Toti built this studio for me. Then I was able to build on my own. I built ten more houses in Bichinho. The property where the gas station [is located] belongs to me. The other house as well. The house where Oficina de Agosto's shop used to be. The other one belongs to my daughter. And all that came from [my work in my studio] here. ( . . . ) I rent them out for income. I built a gym and physiotherapy clinic for my daughter in Tiradentes. (Former employee at OdA)

The story of Bichinho's newer generation fascinates Toti himself:

Young people are following new paths, one wants to be a fashion designer, the other wants to work with tourism. Lili left Oficina to be a teacher. ( . . . ) I didn't go to college. So going to college, for me, was something extraordinary. ( ... ) [The new generation] is going to college. We are very proud. ( . . . ) But I think that starting with arts and crafts gives you good background experience. So, Oficina de Agosto is a starting point for different careers. (Toti, social entrepreneur at OdA)

Besides those stories, we were able to identify many other compelling narratives in Bichinho. There is Toti and the power of an individual vision. There is the move from individual art to collective art. There is the generative nature of SE, in how it creates jobs, encourages entrepreneurship and ecosystem development, and confers dignity and hope. A managerial recommendation would be to create a community and visitors center, both online and bricks-and-mortar, to collect and exhibit these compelling narratives in a strategic community building effort. Partnering with private companies could bring the necessary financial resources, as exemplified by the Casa de Cultura de Paraty [44] and the Casa Gallina in Mexico City [37]. 


\subsection{E Is for "Engaging Both/And Thinking"}

Brazil has a long history of dualities, as mentioned in Section 1.1. One of the most important anthropological treaties on Brazil owes its title specifically to one of those dualities: "The Masters and the Slaves" [4]. Doing SE in Brazil might be particularly challenging, as the conflicting polarities onto which Brazilian culture was built meet the opposing forces inherent to all regenerative organizations. While it might be common to understand those opposing forces as either/or propositions with winners and losers, a patient both/and mindset might work as a fifth principle for community regeneration.

OdA'a success as an SE is largely based on both/and thinking. Toti was capable of extracting opportunity out of seemingly conflicting objectives: to better the community and, at the same time, make a profit. He did it by tirelessly trying to improve his employees' individual and communal lives. He did it by assessing local capacities and helping needleworkers and construction workers transition into more profitable careers in the arts and crafts. He did it by channeling local beauty into expensive products that matched wealthy consumers' interests, linking insiders with outsiders. He did it by focusing on positive narratives and on solutions, instead of dwelling in the past and on the problems. Above all, he did it by dismantling a hierarchical system through which Bichinho's residents had been colonized, devalued, and silenced for centuries.

The 1990s in Brazil were times of economic prosperity, with the population's upward mobility and increased buying power that resulted from Plano Real, a set of measures taken to stabilize the economy, which were capable of taming inflation [45]. With the extra income, many Brazilians entered new consumption arenas, such as home decor. At the same time, Brazil lived a cultural movement of national identity building and started to take pride in its handicraft and folk art, with production centers gaining visibility all over the country [3]. These jointed characteristics of the economic and the cultural macroenvironments facilitated OdA's success and allowed the SE to charge premium prices that, in turn, enabled Toti to invest back in those individuals who had embraced his project, especially the women striving in a rural village that had been deserted by men. Thus, instead of choosing either a social or an economic business objective, OdA was able to practice both.

Colonial and baroque art and architecture are very present in Minas Gerais. The juxtaposition of contemporary or innovative aesthetics with traditional styles is not as common in Brazil as it is in many European countries. Thus, it is hard for Brazilians to wrap their heads around the introduction of contemporary architecture in rustic or colonial environments, such as Bichinho. The either/or mentality seems to guide locals' perception of contemporary architecture as something that "has nothing to do with Bichinho", such as when one of our informants criticized the arrival of different types of businesses, including an inn constructed out of containers, which, in other contexts, could be seen as an environmentally conscious initiative:

I see a growing interest in Bichinho. But not just the small artisan who makes his art in the back yard and then opens up a small door [in the front of his house to sell it]. We're starting to see something different happening. I don't know if this is good. I prefer Bichinho the way it was before I came to live here. You start seeing buildings that have nothing to do with the place. I like adobe [constructions], I like wood. I like white façades with blue, or green doors, you know, the colonial [style]. And even the simplest people here valued it [the colonial style]. You start to see things that are simpler and uglier, I think. Stuff made of containers, for example. I'm not against it, but I wouldn't build something like that. I think Bichinho is transforming, I don't know if that's going to be good. People start to show up, selling things that have nothing to do with Bichinho's history. Even Chinese products. (Entrepreneur in Bichinho)

Brazil seems to lack a culture of architectural preservation that mixes the old and the new, perhaps due to the overly conservative rules adopted for a long time by the National 
Institute of Historic and Artistic Heritage (IPHAN), which used to perceive historical towns, especially the ones in Minas Gerais, as immutable monuments, as art pieces no one should touch [46]. Although more recent perspectives may have moved from towns as monuments to towns as attractions [47], the attempts to introduce contemporary elements into traditional constructions in Brazil may still be received with resistance and controversy. Therefore, to build both/and thinking in aesthetics and design will be an extra challenge in Bichinho.

Slawinski et al. [11] found that the high prices charged by Shorefast's commercial initiatives, the Fogo Island Inn and the Fogo Island Shop, awakened in the locals a new appreciation for their own heritage, since tourists valued the service and products that had been planned in accordance to the place's traditions, and therefore were willing to spend a considerable amount of money to live the Fogo Island experience. Our fieldwork has indicated, so far, that, besides creating jobs and income opportunities for its employees, for other Bichinho residents, and for new entrepreneurs, OdA has also boosted morale, increased well-being, and contributed to a whole range of positive feelings. We did not see, however, an expression of renewed pride in the place arising from OdA's high prices. The expensive prices charged by OdA do not seem to trickle down to its employees in the form of a renewed sense of ownership towards local beauty and capacities. Among former employees there seems to be an understanding that their brand is not as strong as OdA's, and therefore they cannot charge the same high prices, such as in the following account:

[Why doesn't OdA let you sign the pieces?] So that the name of the person who made it won't show. Otherwise, instead of buying from OdA, people would look for us directly. Things are expensive there. With us, it would be cheaper. (... ) Because they have a brand. For some people, their dream is to own a branded piece from OdA. The art pieces are considerably expensive there. (Former employee at OdA)

On top of that, there is the generalized concern regarding the country's economic situation, which also pushes everyone's prices and sales down.

In the next section, we will first compare OdA's case to other SEs. Then we will discuss external threats and internal weaknesses that have been disturbing both feelings and practicalities at $\mathrm{OdA}$ and Bichinho. From there, we will debate Barbosa's [3] view on OdA's current purpose. Finally, we will proceed to suggest ways of addressing place paradoxes and problems that currently affect OdA and other local SEs.

\section{Discussion}

\subsection{How OdA's Case Compares to Other SEs}

Because some members of our team have been working for a long time with marketing and consumer research, adhering to the school of thought known as Consumer Culture Theory (CCT) [48], we were interested in comparing our findings to other studies on SE within this field. However, there is a gap in the marketing, consumer behavior, and CCT literature regarding SE. In order to fill this gap with the present article, we had to resort to the SE literature produced by other areas, such as rural economic development and organizational studies.

In 2005, Tracey, Phillips, and Haugh [49] published an article making the case for a new form of organization they called "community enterprise", which, at that time, could be distinguished from other third sector organizations by its generation of income through trading, rather than philanthropy or government subsidy, to finance its social goals. Community enterprises also included democratic governance structures, allowing members of the community to participate in management activities. The authors advised corporations to establish partnerships with community enterprises, which would move those corporations beyond philanthropic donations, toward a more sustainable form of intervention involving long-term commitments to communities. Said partnerships should build capacity and enfranchise communities in a way that avoids the paternalism of 
donations, because partners are understood as sources of valuable assets, knowledge, and expertise, rather than recipients of charity.

One of our research participants was adamant about the need for public-private partnerships in Bichinho. In practical terms, this could mean building stronger connections, with specific practical goals, between local businesses and the municipality, or between local businesses and federal agencies, such as the University located in the nearby town of São João Del Rei. In light of Tracey, Phillips, and Haugh [49], we envision that larger corporations could be included in those partnerships. Bichinho and local SEs could become the focus of social and environmental responsibility projects conducted by national and international companies with special interest in associating their brands with Minas Gerais' natural and artistic heritage.

However, as pointed out by Tracey, Phillips, and Haugh [49] and by more recent studies we will describe next, active community engagement in those projects is fundamental to their success. A decolonial non-extractivist positioning is necessary for the project to work, to last, and to truly benefit the place. Otherwise, those larger companies risk repeating history by depleting the place of its assets and exploiting its people. With social media's wide reach and increasing general awareness regarding social and environmental issues, exploitative companies can now be exposed with greater speed and ease and, therefore, risk damaging their brand image.

Vázquez-Maguirre [50] studied how four Latin-American indigenous social enterprises, which resulted from major crises affecting individuals' dignity and places' socioeconomic dynamics, contributed to building sustainable rural communities and fostered their well-being. To do so, these SEs followed local principles and governance, while purposefully pursuing dignity protection, sustainability, and cultural reaffirmation. They worked under an alternative model of interaction with the community, based on cooperation and fair distribution of wealth among stakeholders. Community stakeholders participated with active engagement, which limited the potential negative impacts of the SEs and set legitimacy standards in environmental issues, labor rights, transparency, and accountability. The outcomes for communities were good health, decent work, reduced inequalities, public infrastructures, sustainability, synergetic partnerships, and human flourishing.

In the completely different context of Scotland, Finlayson and Roy [35] reported that the government and development bodies were increasingly stimulating SE activity in communities as an empowering social and economic intervention. However, this type of externally facilitated SE, the authors alerted, could end up actually disempowering community members, particularly when SE development did not align with community needs. The authors defend that certain roles in the SE must be community-led, and that community participation should start at the project planning stage.

The aforementioned studies and the ones we will present next show that networking is central to social entrepreneurship. Our context attests to the fact that networking does not come easily. It demands deliberate strategic efforts to get locals to unite and organize around a cause. Connecting insiders and outsiders is also a sensitive task, as illustrated by Bichinho's case, but success can be achieved with a patient non-hierarchical approach, such as the one adopted by Toti. Other benefits and barriers to networking appear in the following paragraphs.

Maher and Hazenberg [51] explored the barriers faced by SE-led community energy projects in Vietnam, arguing that one mandatory competency for SEs is their ability to network. However, their research context was characterized by resistance to networking opportunities, because of the Vietnamese government's active involvement in markets. The authors found out that communities with little political capital were alienated from state institutions, while enterprises that offered alternative solutions to governmental priorities were seen as competitors by political agents. They conclude that the impact of large, hegemonic institutions can hinder the networking ability of SEs and harm their beneficiaries.

Berno's [52] SE research also testified to the importance of the network, focusing on SE's power to reconnect. The author looked into the role of social entrepreneurs and local 
food systems in building community resilience in a post-earthquake New Zealand city. The study indicates that a network of local food SEs emerged (i.e., organic/biodynamic agriculture, urban agriculture, community supported agriculture, farmers markets, community gardens, and hyper-local restaurants), sharing the common goal of building multiple and unique forms of capital (human, social, natural, financial, and physical). This case illustrates a collective mobilization of local resources and a network of producers bound by place. The author accentuates the potential of local food-system-related SEs as a means of providing an alternative development model to reconnect communities with their own local resources.

Anderson and Gaddefors [53], too, emphasized reconnection as an important outcome of SEs. Their context was a small depleted rural town in Sweden, where a sense of belonging had been renewed and a sense of place meaning had been strengthened by an SE. Their unit of analysis was entrepreneurship in its societal context, focusing on an organization that included gardens, a forestry park, a restaurant, courses, workshops, exhibitions, and other events. The authors indicate that the emergence of this SE fired up a whole chain of entrepreneurial actions. Thus, they conceive entrepreneurship not only as a practice of making connections between people, but also of reconnecting the past and the present, imbuing the community with a new sense of confidence, purpose, and belonging.

We clearly saw in Bichinho how OdA created fertile ground for the emergence of many other companies, following either traditional business models or more socially and environmentally conscious models. The town became a touristic destination due to the connections OdA made and encouraged.

We also saw Toti's personal inclination for embracing people with vulnerabilities, which naturally overflew to his SE's recruiting strategies. The next studies deal precisely with SE's potential to include marginalized communities, like OdA did.

Ottlewski [54] investigated a German online SE created to inform, protect, connect, support, and normalize non-traditional families, considering their actual and aspiring members as part of a marginalized community that is left in an institutional void not filled by the market or by any governmental institutions. This SE was created by members of the community it intended to serve: two lesbian women who felt excluded from the socially and legally accepted pathways to becoming parents.

Farmer et al. [55] examined how the well-being created when an individual is part of an SE may expand to other realms of their everyday community lives, through positive interactions with people, material objects, stories, and performances. Their context was an Australian work integration SE, providing vulnerable people with social integration opportunities, social capital building, and sheltered or supported employment. In this case, well-being is linked with improvements in mental health, self-confidence, self-esteem, motivation, and life satisfaction. The study revealed that participants developed within the SE a sense of mobile well-being, which would travel with them into the community. Places and things acted as triggers for participants' expressions of well-being outside the SE. They also reenacted their sense of well-being by telling stories about how the SE improved their community lives. Furthermore, they experienced well-being outside the $\mathrm{SE}$ via performances, such as being a calmer, non-disruptive, better-adapted member of the community.

OdA's particular case extend all these studies by raising awareness to the possibility that an SE's social purpose may not be perennial or unshakable, as we will discuss next. Can long-lasting economic crises and a history of subalternation deplete social enterprises of their original social objective, even if it was the reason for their birth in the first place? We sincerely hope that the answer to this question is negative. To contribute to that, in the following section, we suggest ways to manage the paradoxes of place in Bichinho, so that OdA's (and other SE's) social character may endure even in the face of distress. 


\subsection{Managing the Paradoxes of Place in Bichinho}

The three main problems that have been affecting OdA, Bichinho's residents, and other local arts and crafts businesses are the repeated world economic crises since 2007 in general, and the Brazilian economic and political crisis from the past four years in particular; a local culture of copy and counterfeit; and the serial production of folk art by invading larger companies with extractivist behavior and no connection to place.

With decreased buying power, fewer tourists are inclined to buy the expensive items sold by OdA, forcing price reductions and layoffs. While Toti has encouraged his apprentices to leave OdA and open up their own shops, empowering them towards autonomy, he has also been pressured to do so in order to reduce the number of employees on OdA's payroll. A former employee recalled: "Those who had the ability to create art flourished and opened up their own studios. I worked there for many years, then Toti said 'B., with your abilities and great performance, I can no longer pay you. You're going to have to start your own studio'."

Because everything that came out of OdA was a collective effort, those who started their own business, selling part of their production to OdA and the rest to other clients, felt entitled to the new themes and aesthetics they had helped create [3]. However, those best-selling items, such as the holy ghost represented as an open-winged white dove laying on a bed of flowers, did not remain exclusive productions of OdA and its former employees. Every new arts and crafts store in Bichinho and surrounding towns had those items in stock, proliferating an unabashed copy-cat culture that not even copyrights could placate. One of our informants showed us many copyright certificates he had had issued for his creations, which did not protect them from being copied, since law enforcement and judicial trials are so ineffective in Brazil.

When asked about how he felt seeing his ideas and creations being sold in almost all arts and crafts stores in Bichinho and nearby towns, Toti replied with generosity:

[How do you feel about all the people who have copied from you, from OdA?] That was the idea for starters. The idea was that people would take the originals and give them continuity, transforming them as well. But that's difficult. In order to do that, they would have to travel, they would have to see things. [Don't you get offended by the copies?] No, absolutely not. The teachers [trained here] get a little offended, because it's their livelihood. So, if the neighbor starts doing something similar ... But, in the end, it all works out. Because it sells over there, but it also sells here. We used to be the only ones selling. Now, we are 400 arts and crafts shops sharing the sales. It's not the same product, but the good thing is the influx of visitors. (Toti, social entrepreneur at OdA)

The possibility of copying best-selling items seems to have attracted larger companies from out of state, with which local artisans cannot compete, as described by one research participant:

Before, it was better. Before, you were able to sell everything you made. It wasn't crazy like it is now, with these megastores making loads of money, steamrolling the small ones. So, some of us are left behind. Me, for instance, I should have a shop on the main street. But how would I pay for rent? Rent is crazy ( . . ) A lot of them say it's their own production. But it isn't. ( . . . ) Unlike me, I sculpt it from scratch. ( . . ) Angela's restaurant is selling like crazy. It was on the New York Times. So, tourists started coming. It became this madness. In the past years, there have been traffic jams in the weekends. Nobody moving forward nor backwards. Now it's a little less [busy]. (Former employee at OdA)

The recent decline in the number of people visiting Bichinho was thus explained by another former OdA employee:

Before, tourists used to come all the way from São Paulo [just] to visit Oficina de Agosto. Then people started buying from us once, twice. They learned how 
we did it, and opened up their own stores out of here. They hired a welder and started making stuff. ( . . . ) Arts and crafts were banalized. There are factories that make [folk art] now. ( . . ) So, people think "why will I go all the way to Bichinho, if I can buy the same things in Prados? Or in Tiradentes". ( . . ) The road should be paved. People with expensive cars stop half-way because of the road's condition. (Former employee at OdA)

A local entrepreneur not working with folk art thus explained why OdA lost many of its customers:

The customers who used to visit Bichinho because of Oficina de Agosto don't come here anymore. Because in tourism ... In almost every business, you have to choose your target audience, right? If you're going to make cachaça, who are you going to sell to? What kind of cachaça, packaging, what market are you targeting? Tourism is the same thing. One type of audience does not cohabitate with another type of audience. (... ) So the tourists who came here, who were willing to pay $\mathrm{R} \$ 10,000$ (around U\$2000) for a work of art, they don't come here to share the space with these customers that come today, by van, by bus. It became too popular, right? The upper-class audience with more money, they want more exclusive stuff, right? Which is what we used to have here: exclusivity. (Entrepreneur in Bichinho)

Barbosa [3] critically analyzed OdA with an anthropological approach for her doctoral dissertation in the field of Contemporary Studies. Her discussion did not contemplate the concept of SE, nor did it focus specifically on entrepreneurship or sustainability. Focusing, rather, on the artisanal production of postcolonial identity narratives, she argues that market demands, profitability, and competitiveness have increasingly affected OdA's power relations with its current and former employees, modifying its initial purpose as an inclusive, non-hierarchical, collective project. Barbosa [3] believes OdA is now a private company aiming predominantly at profit, which naturalizes layoffs as a necessary outcome of ongoing economic crises, creating precarious labor relations and discourses that blame workers as lazy, internalized sometimes by the workers themselves. The attempt at controlling authorship of what used to be communal art is, for Barbosa [3], evidence of the hierarchical system based on capitalism within which OdA now operates. When Barbosa [3] conducted her fieldwork, she found out that Sonia, Toti's sister, had visited Bichinho threatening to sue former OdA employees who were producing and selling pieces similar to OdA's. At this point, the author indicates Toti's subalternate position, in what she called an "internal colonization" [3] (p. 365), since he did not oppose the copies, but seemed outranked by his sister. Because her analysis is based on either/or thinking, Barbosa [3] reproduces binary oppositions (Sonia/Toti), in which the capital wins over the social. But what if we could have both, like OdA once did in the past?

Poststructuralism has taught us that language constitutes our reality because it endows phenomena with specific meanings, reflecting and constructing a hierarchical system in which conceptual opposites (such as culture/nature, masculinity/femininity, mind/body, reason/emotion, and production/consumption) depend on each other for their meaning. Therefore, the conflation of opposites does not serve those who are at the top edge of said hierarchies because they risk losing their superiority [56]. This explains why, in the Brazilian case, the historical binary oppositions of master/slave, white/indigenous, white/black, men/women, superordinate/subordinate, colonizer/colonized, and many others, still linger or have left profound marks. Overlapping those competing forces sit the oppositions that are inherent to ecologically and socially embedded organizations such as OdA: insider/outsider, traditional/contemporary, local/global, place-based/placeless, and social/economic, to name just a few. All these forces that resist the conflation of opposites lead to the assumption that the only way is an either/or way, hindering both/and mindsets and clouding a third path. 
Slawinski et al. [11] offer a model for managing the paradoxes faced by place-based SEs. For these authors, place-based tensions should be purposefully triggered, although they are likely to occur anyway. In their study, linking insiders and outsiders and trying to introduce modern elements into a traditional place were the conceptual categories that triggered place-based tensions. In practical terms, Shorefast brought insiders and outsiders together by hiring consultants to work with local employees in order to share knowledge and build capacity, and by inviting local residents to act as hosts to Fogo Island Inn's guests, enabling them to share their experiences with one another. To introduce modern elements into a traditional place, Shorefast incorporated modern architecture into a traditional landscape, introduced modern design into traditional furniture and textile making, and mixed hospitality best practices with Fogo Island's own approach to hospitality. With all that, tensions were fired.

What the authors learned was that the conceptual categories necessary to paradoxically manage placed-based tensions are to create conditions for meaningful exchange and to take a patient approach. To do so, it is necessary to encourage respectful and symmetrical learning exchanges, boosting insiders' and outsiders' appreciation for the place, adopting insiders' own terms, while letting outsiders experience local culture. This cannot be achieved in a hurry. A long-term approach allows the strengthening of local capacities and the emergence of better information, before closure is reached. The outcome, according to these authors, is the regeneration of place, in the form of an appreciation for the value of local assets, a renewed pride in place, increased community well-being, and enhanced built and natural environment.

From all we have learned about OdA and Bichinho, we know that this SE has gone, perhaps intuitively, through many of the aforementioned conceptual categories, obtaining similar results to those obtained by Shorefast in terms of community development. However, in order to manage new and current challenges, OdA and other SEs working in small Brazilian towns could benefit from Shorefast's experience.

The following managerial recommendations regarding the paradoxes of place in Bichinho emerged when our research participants' discourses were interpreted in light of paradox management theory. Older community champions could identify, encourage, and sponsor new community champions that are inherently inclined to tirelessly fight for Bichinho's improvement. Organized groups made up of older and newer community champions could trigger new tensions and, therefore, new opportunities, by inviting outsiders to work with insiders, in a long-term and non-hierarchical fashion. These groups could, together, assess local capacities in other domains besides folk art, such as archaeology, botany, architecture, food and beverage, religiosity, and many more. While new capacities are built, parallel educational opportunities should be constructed to help locals successfully manage their businesses and their profits. The juxtaposition of the contemporary and the traditional would be an added challenge, bound to generate tensions due to the scarcity of national examples that successfully match old and new aesthetics. However, as we have learned, tensions are fertile ground for opportunities. A community and visitors center, perhaps based in the social center already existent in Bichinho, could house an effort to collect and exhibit compelling local narratives and a program of artistic residencies. Partnerships between the public and the private sector could help fund these initiatives. Three tenets should guide the overarching mindset: long-term patience, non-hierarchical relationships, and a constant effort to practice both/and thinking until win-win solutions arise.

\section{Conclusions}

Combining the methods of ethnography and ABR, under an inductive-deductive perspective, this study had the objectives of analyzing the catalytic role of OdA in Bichinho's economic and cultural revitalization; discussing the local conditions that set the SE to success; understanding the importance of place, entrepreneurial ecosystems, local perspectives, and processes; identifying OdA's forces but also its boundaries, limitations, and challenges; and providing managerial recommendations that may help entrepreneurs 
in Bichinho deal with the tensions that emerge from the juxtaposition of the social and the economic, the traditional and the contemporary, the local and the global, and the insider and the outsider.

In an attempt to reach said objectives, this study, first, told the story of how OdA was installed in Bichinho, describing its historical antecedents and its social and economic consequences. Then, following the P.L.A.C.E. model, we commented on the social entrepreneur's role as a community champion and uncovered the need for promoting new champions. Important links between outsiders and insiders were identified, especially the ones brought about by the social entrepreneur under focus, who was capable of connecting local artisans with his former big city clientele. Assessing local capacities was one of the main reasons for OdA's success, since Bichinho's dwellers were needleworkers and construction workers, willing to learn new skills to improve their well-being and family ties. The place's natural beauty was also a local strength potentialized by OdA's entrepreneur, who included it in the SE's aesthetic repertoire. Compelling narratives were found among current and former employees, always framed by the entrepreneur in a positive, constructive light. Finally, OdA's growth was built on both/and thinking, fostered by a prosperous economic and cultural macroenvironment in the 1990s. Now, with repeated crises, including the recent pandemic, a both/and approach does not seem to flourish as easily as before; however, it may still be the solution to current business and societal challenges.

As a context-bound contribution, this study suggested business and community practices based on long-term patience, non-hierarchical relationships, and a constant effort to adopt both/and thinking. Nevertheless, we do not wish to frame all the ideas contained in our managerial recommendations as ours. This is a non-extractivist research that intends to work as a repository and vehicle for the ideas that were already latent among our informants (the real owners of great part of the information herein divulged), while providing new insights that sprouted from our own interpretive analysis of data. We tried to protect their identities, not labeling quotes with participants' names whenever possible. It is not our intention to claim authorship of our informants' suggestions, and we would like to give them all the credit they deserve, but without exposing their identities when they talked about sensitive topics.

The context-transferable conclusions we have arrive at are three-fold: (1) as previous studies have shown, social enterprise may indeed work as an alternative market model that could support community building; (2) social enterprises' initial social focus may not be perennial or unshakeable, which might require both/and thinking and a patient management of paradoxes; and (3) the managerial recommendations herein offered might be extended to other businesses in Bichinho, in other semi-rural Brazilian towns, or even in international settings that might bear economic and social resemblance to our researched context. Future research could try to explain how social enterprise, as an alternative market model, may impact traditional business models, either in the context of semi-rural towns or in larger cities.

The main limitation of this study has to do with the access to OdA's current employees. We have framed them as important subjects of the larger study of which the present article is a part, but, so far, we have only interviewed one of them (see Table 1). Future steps in our project include ABR-based interviews with artists currently working at OdA. Since we propose a patient both/and approach to knowledge building, we believe that future investigations of Bichinho's SEs, including our own, should work with long-term in loco participant observation.

Author Contributions: Conceptualization, L.W. and C.E.F.d.C.; methodology, L.W. and C.E.F.d.C.; formal analysis, L.W. and C.E.F.d.C.; investigation, L.W. and C.E.F.d.C.; resources, L.W. and C.E.F.d.C.; data curation, L.W. and C.E.F.d.C.; writing-original draft preparation, L.W.; writing-review and editing, L.W.; visualization, L.W. and C.E.F.d.C.; supervision, L.W. and C.E.F.d.C.; project administration, L.W. and C.E.F.d.C.; funding acquisition, L.W. and C.E.F.d.C. All authors have read and agreed to the published version of the manuscript. 
Funding: This research was partly funded by Apoio à Criação e Circulação Artística da UFSJ, PróReitoria de Extensão e Assuntos Comunitários, Universidade Federal de São João Del Rei.

Informed Consent Statement: Informed consent was obtained from all subjects involved in the study.

Data Availability Statement: Data sharing not applicable.

Acknowledgments: We would like to thank John Schouten for his participation and support of this study. We would also like to thank the reviewers of this Special Issue.

Conflicts of Interest: The authors declare no conflict of interest.

\section{References}

1. Askegaard, S.; Linnet, J.T. Towards an Epistemology of Consumer Culture Theory: Phenomenology and the Context of Context. Mark. Theory 2011, 11, 381-404. [CrossRef]

2. Darlington, S.; Glanz, J.; Andreoni, M.; Bloch, M.; Peçanha, S.; Singhvi, A.; Griggs, T. A Tidal Wave of Mud: A Mining Dam Collapsed and Buried More Than 150 People. Now Brazil Is Casting an Anxious Eye on Dozens of Dams Like It. The New York Times. 2019. Available online: https://www.nytimes.com/interactive/2019/02/09/world/americas/brazil-dam-collapse.html (accessed on 1 September 2021).

3. Barbosa, V.L.E. De Arraial do Bichinho a Vitoriano Veloso: A Confeção Artesanal das Narrativas Identitárias de um Povoado nas Minas Gerais do Brasil. Ph.D. Thesis, Universidade de Coimbra, Coimbra, Portugal, July 2018.

4. Freyre, G. Casa-Grande E Senzala-Formação da Família Brasileira sob o Regime da Economia Patriarcal; Global: São Paulo, Brazil, $1933 / 2006$

5. Prado, C., Jr. Formação do Brasil Contemporâneo; Brasiliense: São Paulo, Brazil, 1945.

6. Cardoso, M.T. Bichinho e Gritador: Cultura e Identidade em Povoados Camponeses. Master's Thesis, Universidade Federal de Minas Gerais, Belo Horizonte, Brazil, December 1992.

7. Kerlin, J.A. Social Enterprise in the US and Europe: Understanding from the Differences. Volunt. Int. J. Volunt. Nonprofit Organ. 2006, 17, 246. [CrossRef]

8. Chell, E. Social Enterprise and Entrepreneurship: Towards a Convergent Theory of the Entrepreneurial Process. Int. Small Bus. J. 2007, 25, 5-26. [CrossRef]

9. Porter, M. On Competition; Harvard Business Press: Cambridge, MA, USA, 2008.

10. Schouten, J.W.; Slawinski, N. Strengthening Labrador and Newfoundland through Social Enterprise: A 'PLACE' Model. Memorial University Gazette. 2019. Available online: https://gazette.mun.ca/campus-and-community/op-ed-drs-natalie-slawinkski-andjohn-schouten/ (accessed on 1 September 2021).

11. Slawinski, N.; Winsor, B.; Mazutis, D.; Schouten, J.W.; Smith, W.K. Managing the Paradoxes of Place to Foster Regeneration. Organ. Environ. 2019, 34, 1086026619837131. [CrossRef]

12. Lewis, M. Exploring Paradox: Toward a More Comprehensive Guide. Acad. Manag. Rev. 2000, 25, 760-776. [CrossRef]

13. Smith, W.K.; Erez, M.; Jarvenpaa, S.; Lewis, M.W.; Tracey, P. Adding Complexity to Theories of Paradox, Tensions, and Dualities of Innovation and Change: Introduction to Organization Studies Special Issue on Paradox, Tensions, and Dualities of Innovation and Change. Organ. Stud. 2017, 38, 303-317. [CrossRef]

14. Goldenberg, M. A Arte de Pesquisar-Como Fazer Pesquisa Qualitativa em Ciências; Sociais Record: Rio de Janeiro, Brazil, 2015.

15. Geertz, C. The Interpretation of Cultures; Basic Books: New York, NY, USA, 1973.

16. Denzin, N.K.; Lincoln, Y.S. The Handbook of Qualitative Research; Sage: Los Angeles, CA, USA, 2017.

17. Arsel, Z. Asking Questions with Reflexive Focus: A Tutorial on Designing and Conducting Interviews. J. Consum. Res. 2017, 44, 939-948. [CrossRef]

18. Leavy, P. Handbook of Arts-Based Research; Guilford Publications: New York, NY, USA, 2019.

19. Hervey, L.W. Artistic Inquiry in Dance/Movement Therapy: Creative Research Alternatives; Charles C. Thomas Publisher: Springfield, MA, USA, 2000.

20. Seregina, A.; Christensson, O. Art-Based Research of Consumer Culture. Synnyt Orig. 2017, 2017, 74-84.

21. Seregina, U.A. Co-Creating Bodily, Interactive, and Reflexive Knowledge through Art-Based Research. Consum. Mark. Cult. 2020, 23, 513-536. [CrossRef]

22. Elliott, R.; Davies, A. Using Oral History Methods in Consumer Research. In Handbook of Qualitative Research Methods in Marketing; Belk, R., Ed.; Edward Elgar Publishing: Northampton, MA, USA, 2005; pp. 244-254.

23. Rook, D.W. Let's Pretend: Projective Methods Reconsidered. In Handbook of Qualitative Research Methods in Marketing; Belk, R., Ed.; Edward Elgar Publishing: Northampton, MA, USA, 2005; pp. 143-155.

24. Heisley, D.D.; Levy, S.J. Autodriving: A Photoelicitation Technique. J. Consum. Res. 1991, 18, 257-272. [CrossRef]

25. Ferguson, S.; Brace-Govan, J.; Welsh, B. Complex Contradictions in a Contemporary Idealised Feminine Body Project. J. Mark. Manag. 2021, 37, 188-215. [CrossRef]

26. Walther, L.; Schouten, J.W. Next Stop, Pleasure Town: Identity Transformation and Women's Erotic Consumption. J. Bus. Res. 2016, 69, 273-283. [CrossRef] 
27. Sayre, S. Using Video-Elicitation to Research Sensitive Topics: Understanding the Purchase Process Following Natural Disaster. In Handbook of Qualitative Research Methods in Marketing; Belk, R., Ed.; Edward Elgar Publishing: Northampton, MA, USA, 2005; pp. 230-243.

28. Cunha, V.; Ramalho, C. O Brasil Genial da Oficina de Agosto; Lustre: Rio de Janeiro, Brazil, 2008.

29. Barone, T.; Eisner, E. Art-Based Research; Sage: Los Angeles, CA, USA, 2012.

30. Alami, S.; Desjeux, D.; Garabuau, I. Os Métodos Qualitativos; Vozes: Petrópolis, Brazil, 2010.

31. Van Rensburg, J.; Veldsman, A.; Jenkins, M. From Technologists to Social Enterprise Developers: Our Journey as "ICT for Development" Practitioners in Southern Africa. Inf. Technol. Dev. 2008, 14, 76-89. [CrossRef]

32. Steiner, A.; Teasdale, S. Unlocking the Potential of Rural Social Enterprise. J. Rural Stud. 2019, 70, 144-154. [CrossRef]

33. Gioia, D.A.; Price, K.N.; Hamilton, A.L.; Thomas, J.B. Forging an Identity: An Insider-Outsider Study of Processes Involved in the Formation of Organizational Identity. Adm. Sci. Q. 2010, 55, 1-46. [CrossRef]

34. Smith, W.K.; Gonin, M.; Besharov, M.L. Managing Social-Business Tensions: A Review and Research Agenda. Bus. Ethics Q. 2013, 23, 407-442. [CrossRef]

35. Finlayson, E.; Roy, M.J. Empowering Communities? Exploring Roles in Facilitated Social Enterprise. Soc. Enterp. J. 2019, 15, 76-93. [CrossRef]

36. Hilal, S.; Petti, A.; Weizman, E. The Future Archaeology of Israel's Colonization. Afterall A J. Art Context Enq. 2009, 20, 16-26. [CrossRef]

37. Lafuente, P. Experiences of Common Good, Insite/Casa Gallina: A Project Immersed in a Neighborhood; InSite: Santa Maria la Ribera, Mexico, 2014.

38. Walther, L.; Costa, C.E.F. Wandering in Wonder: From Social Practices to Artistic Practices and Back. In Art-Based Research in the Context of a Global Pandemic; Seregina, U.A., Van Den Bossche, A., Eds.; Routledge: London, UK, forthcoming.

39. Mathie, A.; Cunningham, G. From Clients to Citizens: Asset-based Community Development as a Strategy for Community-driven Development. Dev. Pract. 2003, 13, 474-485. [CrossRef]

40. Baker, T.; Nelson, R.R. Creating Something from Nothing: Resource Construction through Entrepreneurial Bricolage. Adm. Sci. $Q$. 2005, 50, 329-366. [CrossRef]

41. Van Laer, T.; Visconti, L.M.; Feiereisen, S. Need for Narrative. J. Mark. Manag. 2018, 34, 484-496. [CrossRef]

42. Diochon, M.; Anderson, A.R. Ambivalence and Ambiguity in Social Enterprise: Narratives about Values in Reconciling Purpose and Practices. Int. Entrep. Manag. J. 2011, 7, 93-109. [CrossRef]

43. Froggett, L.; Chamberlayne, P. Narratives of Social Enterprise. Qual. Soc. Work 2004, 3, 61-77. [CrossRef]

44. Paes, M.T.D. Trajetórias do Patrimônio Cultural e os Sentidos dos Seus Usos em Paraty (RJ). Resgate: Rev. Interdiscip. De Cult. 2015, 23, 105-118. [CrossRef]

45. Herrán, C.A. Reducing Poverty and Inequality in Brazil; Inter-American Development Bank, Regional Operations Department 1 : Washington DC, USA, 2005.

46. Sant'Anna, M. Da Cidade-Monumento à Cidade-Documento: A Norma de Preservação de Áreas Urbanas no Brasil-1937-1990; Oiti Editora: Salvador, Brazil, 2014.

47. Sant'Anna, M. A Cidade-Atração: A Norma de Preservação de Áreas Centrais no Brasil dos Anos 1990; Edufba: Salvador, Brazil, 2017.

48. Arnould, E.J.; Thompson, C.J. Consumer Culture Theory (CCT): Twenty Years of Research. J. Consum. Res. 2005, 31, 868-882. [CrossRef]

49. Tracey, P.; Phillips, N.; Haugh, H. Beyond Philanthropy: Community Enterprise as a Basis for Corporate Citizenship. J. Bus. Ethics 2005, 58, 327-344. [CrossRef]

50. Vázquez-Maguirre, M. Building Sustainable Rural Communities through Indigenous Social Enterprises: A Humanistic Approach. Sustainability 2020, 12, 9643. [CrossRef]

51. Maher, M.; Hazenberg, R. Floating down the River: Vietnamese Community-Led Social Innovation. Soc. Enterp. J. 2021, 17, 1-19. [CrossRef]

52. Berno, T. Social Enterprise, Sustainability and Community in Post-Earthquake Christchurch: Exploring the Role of Local Food Systems in Building Resilience. J. Enterp. Commun. People Places Glob. Econ. 2017, 11, 149-165. [CrossRef]

53. Anderson, A.R.; Gaddefors, J. Entrepreneurship as a Community Phenomenon; Reconnecting Meanings and Place. Int. J. Entrep. Small Bus. 2016, 28, 504-518. [CrossRef]

54. Ottlewski, L. Building and Strengthening Community at the Margins of Society through Social Enterprise. Sustainability 2021, 13, 12046. [CrossRef]

55. Farmer, J.; De Cotta, T.; McKinnon, K.; Barraket, J.; Munoz, S.A.; Douglas, H.; Roy, M.J. Social Enterprise and Wellbeing in Community Life. Soc. Enterp. J. 2016, 12, 235-254. [CrossRef]

56. Maclaran, P.; Stevens, L. Thinking through Feminist Theorising: Poststructuralist Feminism, Ecofeminism and Intersectionality. In Handbook of Research on Gender and Marketing; Dobscha, S., Ed.; Edward Elgar Publishing: Northampton, MA, USA, 2019. 